Niniejsza publikacja jest dostępna na licencji Creative Commons. Uznanie autorstwa-Użycie niekomercyjne-Bez utworów zależnych 3.0 Polska. Pewne prawa zastrzeżone na rzecz autora. Zezwala się na wykorzystanie publikacji zgodnie z licencja - pod warunkiem zachowania niniejszej informacji licencyjnej oraz wskazania autora jako wtaściciela praw do tekstu. Treść licencji jest dostepna na stronie: http://creativecommons.org/licenses/by-nc-nd/3.0/pl/

Lingwistyka Stosowana 16: 1/2016, 11-22

\title{
Magdalena FILAR
}

Uniwersytet Pedagogiczny im. Komisji Edukacji Narodowej w Krakowie

\section{Złożenia i związki frazeologiczne w tekście i w przekładzie - implikacje dla dydaktyki przekładu}

\begin{abstract}
:
Compounds and Idioms in the Text and Its Translation - Some Implications for the Didactics of Translation

The article discusses the phenomenon of compounds and idioms as a vital issue in the didactics of translation, exemplified by Polish and German. The author applies Langacker's cognitive grammar to the description of compound nouns, explains the partial compositionality of complex linguistic units, presents their semantic types and analyses their semantic potential in the press article entitled Grauer Markt (Der Spiegel 2006/32). The cognitive analysis of its translation equivalents comprises the description of the main difficulties related to the translation of particular types of compounds, both literal and non-literal Polish constructions and the explanation of typical errors made by Polish students.
\end{abstract}

\section{Wstęp}

Zastosowanie kognitywnej teorii języka w przekładzie, zapoczątkowane na gruncie polskim głównie w pracach E. Tabakowskiej (2000, 2001a), pozwoliło na wyeksplikowanie i staranne zbadanie szeregu istotnych zagadnień, które nie były dotąd przedmiotem badań przekładoznawczych. Prowadzone przez autorkę rozważania koncentrują się głównie wokół wywodzącej się z psychologii poznawczej i obecnej także w badaniach literaturoznawczych kategorii obrazowania oraz na metaforze. Wśród omówionych dotychczas w kontekście przekładu aspektów obrazowania znalazły się m.in. perspektywa z kluczową dla jej ustalenia kategorią punktu widzenia, stopień schematyczności sceny, a także wyrazistość i układ figura-tło. Różnice w obrazowaniu wynikające z zastosowania różnych środków leksykalnych i konstrukcji gramatycznych w języku oryginału i w przekładzie są najczęściej analizowane w tekstach literackich, zarówno prozatorskich, jak i poetyckich.

W germanistycznej tradycji badań kognitywna teoria języka jest wykorzystywana głównie w dydaktyce przekładu, np. w rozważaniach nad konceptem jako jednostką sensu w tłumaczeniu (zob. J. Kubaszczyk 2000) i w badaniach nad zagadnieniem kreatywności w przekładzie (zob. P. Kussmaul 2007).

P. Kussmaul zwraca szczególną uwagę na rolę kreatywnego rozumienia tekstu wyjściowego jako pierwszego etapu działania tłumacza i na kreatywne myślenie językowe. 
W celu analizy kreatywnego myślenia językowego tłumacza odwołuje się do modeli kreatywnego myślenia językowego zaproponowanych przez psychologię poznawczą (zob. E. de Bono 1999, E. Rosch 1973) i do kognitywnych teorii języka, w tym do gramatyki kognitywnej (zob. R. Langacker 1987), kategoryzacji przez prototyp, a także do będącej jej rozszerzeniem koncepcji łańcucha powiązań (zob. G. Lakoff 1987) oraz semantyki ram i scen (zob. Ch. J. Fillmore 1976, 1977) ${ }^{1}$. Swoje analizy przeprowadza na tekstach o różnych funkcjach komunikacyjnych.

W nawiązaniu do prac J. Kubaszczyk (2000) i P. Kussmaula (2007) chciałabym przyjrzeć się bliżej zagadnieniu złożeń i związków frazeologicznych w tekście i w przekładzie. Rozważania będą się koncentrować w szczególności na omówieniu struktury i potencjału znaczeniowego złożeń, w tym także na opisie okazjonalnych złożeń powstających na potrzeby danego tekstu, i na analizie ich odpowiedników w języku docelowym pod kątem ich ekwiwalencji z tekstem wyjściowym. Jako materiał do analizy posłuży niemiecki tekst prasowy pt. Grauer Markt („Der Spiegel” 2006/32) i jego przekłady na język polski wykonane przez studentów w ramach warsztatów thumaczeniowych.

\section{Znaczenie $w$ tekście i w przekładzie}

Spośród wymienionych wyżej teorii punktem wyjścia dla naszych rozważań jest gramatyka kognitywna R. Langackera (1995, 2005b, 2009), głównie ze względu na kompleksowość omawianych zagadnień, a także ze względu na dynamiczną i encyklopedyczną koncepcję znaczenia. Langacker, podobnie jak inni kognitywiści, przyjmuje, że znaczenie nie jest zawarte w języku, lecz że jest tożsame z konceptualizacją, tzn. jest każdorazowo konstruowane $\mathrm{w}$ umyśle konceptualizatora na potrzeby danej sytuacji i w interakcji z innymi uczestnikami dyskursu. W odróżnieniu od pozostałych badaczy postuluje również, że na znaczenie wyrażenia językowego składa się nie tylko określony układ treści pojęciowych, ale także sposób ich przedstawiania przez mówiącego, określany także jako konstruowanie sceny lub konwencjonalne obrazowanie. Mówiący konceptualizator może na przykład konstruować tę samą scenę na różne sposoby, dokonując wyboru w zakresie poziomu uszczegółowienia konceptualizowanej sceny, zakresu predykacji, perspektywy oraz poziomu wyróżnienia konceptualizowanych obiektów (profilowanie, układ figura - tło). To, który sposób konstrukcji sceny wybierze, zależy od szeroko rozumianego kontekstu pragmatycznego wypowiedzi.

Przyjęcie takiej koncepcji znaczenia w przekładzie oznacza, że główne zadanie tłumacza jako pierwszego odbiorcy tekstu polega na rekonceptualizacji tego, co w tekście wyjściowym chciał przekazać autor, określeniu zakresu rozumienia tekstu przez odbiorców języka wyjściowego, a następnie na rekonstrukcji tych treści dla odbiorcy w języku docelowym. Ekwiwalencja w takim ujęciu jest więc ekwiwalencją na poziomie interpretacji tekstu w umysłach odbiorców oryginału i przekładu, w rozumieniu E. Tabakowskiej (2001a: 99) ekwiwalencją na poziomie obrazowania. Podstawową jednostką do thumaczenia jest wobec tego jednostka tekstu odpowiadająca scenie, a w ujęciu J. Kubaszczyk (2000) jednostka mniejsza odpowiadająca pojęciu, zarówno złożonemu, jak i szczegółowemu.

${ }^{1}$ Bibliografia prac dotyczących modeli kreatywnego myślenia w psychologii poznawczej i kognitywnej teorii języka za P. Kussmaul (2007: 81-122). 
Tłumaczenie polega więc na zastąpieniu pojęcia wyrażonego w języku wyjściowym identycznym lub maksymalnie podobnym pod względem znaczeniowym konstruktem wyrażonym w języku docelowym. Jest to możliwe poprzez nałożenie na treści kognitywne leżące $u$ podstaw pojęcia w języku wyjściowym schematów organizacji treści języka docelowego, przy czym należy dążyć do zachowania maksymalnej identyczności pojęć (J. Kubaszczyk 2000: 81, tłum. M.F.).

Zaproponowana przez Langackera analiza treści pojęciowej wyrażeń w odniesieniu do domen kognitywnych i parametrów konstrukcji sceny może stać się także przydatnym narzędziem badawczym w analizie różnic w sposobie konstrukcji znaczeń w tekście wyjściowym i docelowym, a także w określaniu stopnia ekwiwalencji powstałych w przekładzie scen.

\subsection{Złożenia i związki frazeologiczne w gramatyce kognitywnej}

Gramatyka kognitywna Langackera formułuje dwa założenia szczególnie istotne w kontekście analizy znaczenia w tekście wyjściowym i w przekładzie. Pierwszym z nich jest teza o symbolicznej, a więc znaczeniotwórczej naturze gramatyki, drugim teza o niepełnej kompozycjonalności wyrażeń językowych (ang. partial compositionality), określana również jako zasada niepełnej rozkładalności na składniki.

W gramatyce kognitywnej termin złożenie jest rozumiany w specyficzny sposób, ponieważ odnosi się do złożenia symbolicznego, a więc do podstawowej jednostki językowej i gramatycznej, i oznacza konwencjonalne połączenie jednostki semantycznej z jednostką fonologiczną, ściślej związek między biegunem semantycznym a fonologicznym jednostki. Ze względu na strukturę symboliczną wyróżnia się proste złożenia symboliczne, które nie ulegają dalszemu rozkładowi, takie jak morfemy fleksyjne i słowotwórcze, oraz złożenia wieloelementowe, które składają się z mniejszych jednostek symbolicznych - konstrukcje.

W przypadku takich konstrukcji jak złożenia rzeczownikowe dochodzi do połączenia dwóch elementów nominalnych. Wyznacznikiem profilu, tj. członem głównym w tak powstałej strukturze semantycznej, jest zawsze drugi element składowy, np. złożenie Haustür dziedziczy swój profil po rzeczowniku Tür i w rezultacie profiluje ten sam typ obiektu co człon główny. Na wartość semantyczną złożeń składa się określony układ treści pojęciowych, a także relacja znaczenia wyrażenia złożonego do jego komponentów czyli tzw. ścieżka kompozycjonalna. Dane złożenie reprezentuje konwencjonalny sposób dostępu do zbioru domen kognitywnych. Jego użycie w różnych kontekstach powoduje, że pewne domeny pełnią funkcję domen centralnych, inne natomiast pełnią funkcję domen peryferyjnych i są rzadziej aktywowane ${ }^{2}$. Mamy w tym przypadku do czynienia ze zjawiskiem dostosowania kontekstualnego zakresu aktywacji domen kognitywnych. Ze względu na stopień rozkładalności i czytelności przyjmuję za M. Schwarz/ J. Chur (2007: 111-114) rozróżnienie na złożenia transparentne, złożenia zleksykalizowane oraz złożenia okazjonalne. Do grupy złożeń transparentnych semantycznie należą

${ }^{2}$ Termin domena kognitywna zdaniem R. Langackera (2005b: 16) odpowiada temu, co Fillmore określa jako rama semantyczna, a George Lakoff jako idealizacyjny model kognitywny (Idealized Cognitive Model - ICM). 
złożenia, których znaczenie jest w pełni kompozycjonalne, tzn. wynika ze znaczenia poszczególnych części składowych. Możemy wśród nich wyróżnić złożenia, które bazują na znaczeniu podstawowym lub rozszerzonym elementów składowych, takie jak np. Finanzmarkt, Arbeitsmarkt, Arbeitgeber. Treść pojęciowa tych złożeń jest ustalana w odniesieniu do domen gospodarki i ekonomii. Ciekawym pod względem semantycznym typem złożeń są zwłaszcza złożenia okazjonalne, w których znajomość znaczenia struktur składowych nie wystarcza do ich pełnego zrozumienia. Dobrym przykładem może być złożenie Rettungsroutine (słowo roku 2012). Konstrukcja Rettungsroutine jest terminem informatycznym i w konwencjonalnym znaczeniu oznacza program komputerowy zabezpieczający dane przed utratą w przypadku awarii. W konwencjonalnym znaczeniu aktywuje więc takie domeny, jak technologia komputerowa, system zabezpieczający, automatyzm, biegłość. W żargonie medialnym i politycznym zaczęto go jednak używać na określenie stałej pomocy finansowej udzielanej krajom członkowskim w ramach Unii Europejskiej, które najbardziej dotknął kryzys finansowy w Europie. Takie użycie tego złożenia powoduje pozostawienie wśród domen centralnych domeny automatyzmu, ale aktywuje równocześnie inne struktury wiedzy jako centralne, np. kryzys finansowy, programy pomocowe UE, waluta Euro, zadłużenie, wiarygodność kredytowa ${ }^{3}$.

Analiza przytoczonych przykładów pokazuje więc, że całościowe zrozumienie znaczenia struktury złożonej wymaga także znajomości szerszego kontekstu oraz wiedzy o świecie, do której wybrana struktura złożona odnosi się tylko pośrednio (zob. E. Tabakowska 1995: 95).W porównaniu z takimi konstrukcjami jak Finanzmarkt i Rettungsroutine inny przypadek stanowią zleksykalizowane złożenia i związki frazeologiczne, jak np. Flohmarkt i grauer Markt/szary rynek. Złożenie Flohmarkt oznacza rodzaj bazaru, na którym można nabyć lub wymienić różne produkty, często używane, po niskich cenach, jego znaczenie nie wynika więc ze znaczenia części składowych. Z kolei związek frazeologiczny grauer Markt/szary rynek cechuje większa rozkładalność na płaszczyźnie fonologicznej niż na płaszczyźnie semantycznej. Całe wyrażenie jest odbierane jako skonwencjonalizowana jednostka treści i oznacza „działalność niezgodną z obowiązującymi przepisami lub niezarejestrowaną działalność gospodarczą" (Duden Wirtschaft /SJP PWN), również w tym przypadku cecha nielegalności nie wynika ze znaczenia części składowych związku frazeologicznego ${ }^{4}$.

\subsection{Zlożenia i związki frazeologiczne w tekście prasowym pt. Grauer Markt}

Będący przedmiotem analizy tekst prasowy z zakresu gospodarki pt. Grauer Markt pochodzący z tygodnika „Der Spiegel” (2006/32) cechuje z jednej strony duży potencjał obrazotwórczy, metaforyczność i nacechowanie emocjonalne, a z drugiej - duży stopień fachowości, skrótowość sformułowań i kondensacja treści, wynikające z użycia w tekście terminologii ekonomicznej w języku niemieckim i angielskim. Wszystkie te cechy

\footnotetext{
3 Szczegółową analizę semantyczną złożenia Rettungsroutine przeprowadza J. Bär (http://www.duden.de).

${ }^{4}$ Szerszej problematyką związków frazeologicznych w tym paradygmacie badawczym zajmuje się gramatyka kognitywna J.R. Taylora (2007).
} 
semantyczne tekstu możemy obserwować już w tytule i w wielu złożeniach rzeczownikowych.

\author{
Grauer Markt \\ Während Franz Müntefering mehr Arbeitsplätze für Ältere schaffen will, erleben \\ hochqualifizierte Senioren einen zweiten Frühling. Ihr Fachwissen ist gefragter \\ denn je.
}

Dass ihnen ausgerechnet ein Rentner aus der Patsche helfen würde, damit hatten die Pietschmanns nun wirklich nicht gerechnet. Kurz vor Weihnachten hatte ihre Lüftungsfirma Außenstände von 250000 Euro aufgetürmt - und die Hausbank kündigte das Konto. 15 Mitarbeiter bangten um ihren Job. "Wir standen vor der Pleite und haben mit dem Schlimmsten gerechnet", sagt Juniorchef Georg Pietschmann, "bis uns ein Freund den Rat gab: 'Geht doch zum SES."' Der Senior Experten Service (SES) in Bonn schickt Fachkräfte im Ruhestand als ehrenamtliche Entwicklungshelfer rund um den Erdball und seit geraumer Zeit vermehrt in ein nahe liegendes Krisengebiet: den deutschen Mittelstand. Firmen in Not erhalten kostenlose Sofortberatung von einem der etwa 7200 registrierten Senior-Experten. Bloß Spesen und Bearbeitungsgebühren müssen die Unternehmen bezahlen.

$\mathrm{Zu}$ den Pietschmanns im sächsischen Ebersbach fuhr Hans-Reinhard Wimmeroth, 61, der jahrzehntelang ein Baugeschäft geführt hatte. Mit Josef Pietschmann, 62, und dessen Sohn Georg, 29, studierte er den Pleitefall. Unterstützt von zwei weiteren SES-Männern, einem Ex-Wirtschaftsprüfer und einem Anwalt a. D., half er beim Ausfüllen von Formularen, suchte den Kontakt zum Insolvenzverwalter, beschwor die Banken und telefonierte mit Auftraggebern. Wie im TV-Hit "Der große Bellheim" waren es graue Stars, die das Unternehmen schließlich retteten."Im Kern war die Firma gesund, es fehlte nur etwas unternehmerisches Knowhow", sagt Wimmeroth. Die guten Kunden und alle Mitarbeiter wurden schließlich von einer Nachfolgefirma in Familienbesitz übernommen - das 1875 gegründete Geschäft war gerettet.

Solche Rentner-Einsätze machen Schule: Quer durch die Republik vermitteln Gesellschaften und Vereine mittlerweile Fachkräfte im Ruhestand als Berater. Der Gründer Support Ruhr aus Essen beispielsweise stellt jungen Firmengründern erfahrene Ex-Unternehmer zur Seite. Etliche regionale Wirtschaftssenioren- und Alt-hilft-Jung-Vereine unterstützen Start-up- und Problemfirmen.

Auch Konzerne nutzen immer häufiger das Rentner-Wissen. Bosch, Siemens oder der deutsche Ableger des Pharmakonzerns Pfizer etwa engagieren ihre eigenen Ex-Mitarbeiter für dann allerdings gutbezahlte Kurzeinsätze."Der Prozess des Umdenkens ist in vollem Gange", sagt Hans Böhm, Geschäftsführer der Deutschen Gesellschaft für Personalführung. Immer mehr Personalchefs würden erkennen, dass mit Rentner-Einsätzen vorhandenes Know-how rasch, günstig und vor allem flexibel eingekauft werden könne. Zudem kenne oft niemand die Bedürfnisse einer Firma besser als die Ex-Mitarbeiter. Mit Nachwuchsproblemen haben die Rentner-Pools jedenfalls nicht zu kämpfen. Mehr als 20 Millionen Ruheständler leben schon jetzt in der Bundesrepublik. Und es werden immer mehr - auch mit staatlicher Unterstützung (...). [http://www.spiegel.de, 20.07.2015]

W przypadku wykorzystanego w tytule tekstu związku frazeologicznego grauer Markt mamy do czynienia z częściową deleksykalizacją tego wyrażenia i swoistą grą językową. Wyrażenie pierwotnie wprowadzone na gruncie ekonomii na oznaczenie nielegalnej działalności gospodarczej i niosące ze sobą negatywne konotacje zostaje użyte 
na określenie organizacji zrzeszających seniorów aktywnych zawodowo (Senior Experten Service - SES). Deleksykalizacji ulega w tym kontekście słowo grau/szary, które zostaje użyte w swym pierwotnym znaczeniu koloru i odnosi się w tym przypadku bezpośrednio do koloru włosów. W rezultacie wyrażenie grauer Markt zyskuje w tym kontekście nowe nieoczekiwane znaczenie i w przeciwieństwie do zwrotu frazeologicznego nie budzi negatywnych konotacji. Z takim znaczeniem przymiotnika grau/szary mamy również do czynienia w dalszej części tekstu, np. w wyrażeniu graue Stars, które odnosi się do emerytowanych pracowników w telewizyjnym hicie Der große Bellheim oraz w wyrażeniu graumelierte Kunden.

Dla interpretacji złożeń występujących w tekście istotne jest ustalenie, które treści muszą być aktywowane i jakie są semantyczne relacje między elementami składowymi, przy czym przedmiotem analizy są głównie złożenia, które cechuje duża złożoność semantyczna. Seniorzy są przedstawiani w tekście z jednej strony jako wysokiej klasy specjaliści, z drugiej strony jako klienci SES. Służy temu cały szereg złożeń transparentnych semantycznie, takich jak Senior-Experte, Senior-Manager, Ex-Wirtschaftsprüfer, Wirtschaftssenioren-Vereine, aktywujących domenę pracy, oraz konstrukcje Vermitttlungswillige czy graumerlierte Kunden, aktywujące domenę związaną z transakcjami handlowymi. W tej grupie złożeń uwagę zwraca konstrukcja Wirtschaftssenioren-Vereine, którą cechuje skrótowość i kondensacja treści typowa dla języka fachowego. Złożenie powstało na bazie złożenia Wirtschaftsberater i oznacza związki emerytowanych doradców gospodarczych.

Specyfika pracy seniorów w ramach związków SES jest uwarunkowana przez sytuację ekonomiczną i demograficzną w Niemczech, co znajduje wyraz w grupie złożeń okazjonalnych z rzeczownikiem Einsatz występującym w tekście zarówno w liczbie pojedynczej, jak i w liczbie mnogiej. Na przykład złożenie rzeczownikowe Rentner-Einsätze powstało niejako w analogii do często stosowanego złożenia Polizeieinsätze lub frazy Einsätze bewaffneter Streitkräfte i bazuje na podstawowym znaczeniu rzeczownika Einsatz, który prototypowo oznacza akcję, operację, a także interwencję bądź misję, np. policji lub wojska, zwykle w sytuacji zagrożenia. Jego okazjonalny charakter wynika $\mathrm{z}$ nietypowego pod względem semantycznym zestawienia $\mathrm{z}$ rzeczownikiem Rentner i z użycia rzeczownika Einsatz w nietypowym dla niego kontekście. Celem tego niekonwencjonalnego połączenia jest przede wszystkim wyprofilowanie interwencyjnego charakteru współpracy między przedsiębiorcami a seniorami w celu zażegnania sytuacji kryzysowej na rynku pracy spowodowanej brakiem młodej kadry. W rezultacie emerytowani pracownicy są konceptualizowani jako ci, którzy podejmują się misji ratowania przedsiębiorstw znajdujących się w trudnej sytuacji kadrowej lub ekonomicznej. Potwierdzenie dla takiej interpretacji złożenia Rentner-Einsätze możemy znaleźć w dalszej części tekstu, np. w zdaniu „Sobald die Abteilung funktioniert und der neue Chef eingearbeitet ist, hat der Senior-Manager seine Mission beendet". Tego rodzaju modyfikacja znaczenia zachodzi również w pozostałych złożeniach z rzeczownikiem Einsatz, takich jak gutbezahlte Kurzeinsätze, Einsatztage i BMS-Einsatz (Bosch Management Support - Einsatz).

Ciekawy przypadek stanowią także złożenia Rentner-Pools i Nachwuchsprobleme w zdaniu „Mit Nachwuchsproblemen haben die Rentner-Pools jedenfalls nicht zu kämpfen. Mehr als 20 Millionen Ruheständler leben schon jetzt in der Bundesrepublik. 
Und es werden immer mehr (...)". Złożenie Rentner-Pools powstało w wyniku połączenia rzeczownika Rentner z rzeczownikiem Pool, który jest używany w języku angielskim jako termin ekonomiczny oznaczający „konsorcjum lub też krótkotrwałe porozumienie przedsiębiorców zawierane w celu realizowania konkretnych przedsięwzięć" (SJP PWN). Do pełnego zrozumienia tego złożenia potrzebna jest oprócz znajomości części składowych również wiedza o sposobie funkcjonowania tego rodzaju podmiotów. W tym przypadku chodzi o rodzaj współpracy między koncernami a zakładanymi przez nie spółkami, w których zatrudniani są byli pracownicy. Również drugie złożenie $\mathrm{Na}$ chwuchsprobleme wymaga uruchomienia dodatkowej wiedzy pozajęzykowej. Nie chodzi w tym przypadku o problemy młodej kadry, jak mogłoby wynikać z interpretacji części składowych złożenia, lecz o brak młodych pracowników na stanowiskach specjalistycznych i wskutek tego ponowne zatrudnianie emerytowanych już pracowników. Rzeczownik Nachwuchs odnosi się więc w tym kontekście paradoksalnie i także ironicznie do stale powiększającej się grupy seniorów w Niemczech.

W kontekście całego tekstu i z punktu widzenia przekładu istotny jest również sposób konceptualizowania wieku i wiedzy seniorów, manifestujący się w takich sformułowaniach jak graue Stars, rüstige Rentner, der Nachwuchs czy das in den Ruhestand verabschiedete Fachwissen reanimieren, a także w potocznie stosowanym idiomie zum alten Eisen gehören sygnalizującym częściowo pozytywne, częściowo ironiczne stanowisko autora tekstu. Za sprawą zdania „Immer mehr Personalchefs würden erkennen, dass mit Rentner-Einsätzen vorhandenes Know-how rasch, günstig und vor allem flexibel eingekauft werden könne" wiedza fachowa seniorów jest z kolei konceptualizowana jako obiekt transakcji handlowej. U podstaw tej konstrukcji w planie pojęciowym leży metafora konceptualna, którą na potrzeby tej analizy określam jako WIEDZA FACHOWA TO PRODUKT.

\section{Złożenia i związki frazeologiczne w przekładzie na język polski - analiza kognitywna}

Dalsze rozważania koncentrują się na prześledzeniu procesu decyzyjnego początkujących thumaczy i na analizie zaproponowanych przez nich rozwiązań translatorskich dla wybranych wyrażeń złożonych pod kątem ich ekwiwalencji z tekstem wyjściowym. Analiza rozwiązań translatorskich obejmuje omówienie zarówno ekwiwalentów dosłownych, jak i niedosłownych, a także wyjaśnienie najczęściej popełnianych błędów semantycznych. Pierwsze różnice w sposobie konstruowania wyrażeń złożonych w języku polskim i niemieckim i zarazem pierwsze trudności w przekładzie możemy obserwować już w tytule tekstu oraz w pozostałych związkach wyrazowych z przymiotnikiem grau.

(1) Grauer Markt
(1a) *Szara strefa
(1b) *Szary rynek
(1c) Siwy rynek
(1d) Rynek pracy otwarty dla seniorów

Zasadniczą trudność w przekładzie stanowi w tym przypadku oddanie gry językowej w tytule tego tekstu i znalezienie trafnego ekwiwalentu dla konstrukcji z przymiotnikiem grau. Próba przetłumaczenia wyrażenia Grauer Markt przy pomocy podobnego związku 
frazeologicznego w języku polskim w przykładzie (1a) pozwala na oddanie tylko części znaczenia związanej z prowadzeniem nielegalnej działalności gospodarczej i towarzyszącej mu negatywnej konotacji, nie prowadzi jednak do przekazania zasadniczej treści tekstu, tj. pewnej tendencji na rynku pracy związanej z ponownym zatrudnianiem seniorów przez firmy. Również konstrukcja składniowa Szary rynek w przykładzie (1b) nie spełnia tej funkcji komunikacyjnej, ponieważ przymiotnik szary nie implikuje żadnego odniesienia do seniorów. Pewną alternatywą dla przymiotnika szary może być w tym kontekście przymiotnik siwy, stosowany w języku polskim tylko w odniesieniu do koloru włosów. Wyrażenie Siwy rynek, choć niekonwencjonalne, może odnosić się do fizycznych oznak starzenia, a poprzez to pośrednio również do seniorów i w ten sposób do treści całego tekstu. Zdecydowanie bardziej trafnym ekwiwalentem w tym kontekście jest równoważnik zdania Rynek pracy otwarty dla seniorów. Przywołuje on explicite pojęcie rynku pracy, pojęcie seniora i sygnalizuje zachodzącą między nimi relację za pomocą wyrażenia imiesłowowego otwarty na. Mamy więc w tym przypadku do czynienia z uszczegółowieniem konceptualizowanej sceny, a w szerszym kontekście także $\mathrm{z}$ wyjaśnieniem treści tytułu dla polskiego odbiorcy. Innym, bardziej kreatywnym rozwiązaniem, mogłoby być w tym przypadku także zbudowanie gry językowej na odniesieniu do innego obszaru wiedzy, na przykład do domeny nieruchomości i zaproponowanie jako ekwiwalentu wyrażenia Rynek wtórny, które właśnie tym kontekście i za sprawą przymiotnika wtórny może odnosić się do ponownego zatrudniania seniorów.

Podobne trudności możemy obserwować również w thumaczeniu pozostałych konstrukcji składniowych z przymiotnikiem grau, takich jak graue Stars czy graumelierte Kunden, $\mathrm{np}$.

(2) Wie im TV-Hit „Der große Bellheim” waren es graue Stars, die das Unternehmen schließlich retteten.

(2a) Podobnie jak w telewizyjnym hicie „Der große Bellheim”, siwe gwiazdy uratowały przedsiębiorstwo.

(2b) Podobnie jak w telewizyjnym hicie „Der große Bellheim”, gwiazdami byli również seniorzy/emerytowani pracownicy, ratujący ostatecznie przedsiębiorstwo.

(2c) I tak jak w znanym niemieckim serialu „Der große Bellheim”, seniorzy stali się superbohaterami, którzy ostatecznie uratowali firmę.

Analiza zaproponowanych ekwiwalentów dla wyrażenia graue Stars pozwala zauważyć, że thumaczenie dosłowne w przykładzie (2a) jest wprawdzie poprawne pod względem gramatycznym i znaczeniowym, ale równocześnie trudno akceptowalne w języku polskim. Znaczenie trafniejszymi i bardziej czytelnymi odpowiednikami dla polskiego odbiorcy są $\mathrm{w}$ tym przypadku ekwiwalenty niedosłowne, takie jak seniorzy czy emerytowani pracownicy $\mathrm{w}$ przykładzie (2b) przywołujące zamiast domeny koloru domenę związaną z wiekiem. Ciekawym odpowiednikiem nawiązującym również do niemieckiego oryginału jest także określenie seniorów jako superbohaterów w przykładzie (2c) aktywujące równocześnie domenę związaną z wiekiem i domenę filmu, również przywoływaną w oryginale.

Kolejne zadanie translatorskie polegało na znalezieniu właściwego ekwiwalentu w języku polskim dla złożeń z rzeczownikiem Einsatz/Einsätze-, które ze względu na swoją okazjonalność wymagały nie tylko dokładnej analizy znaczenia, ale także pewnej kreatywności językowej w przekładzie. 
(3) Solche Rentner-Einsätze machen Schule.

(3a) *Takie akcje-emerytów znajdują naśladowców.

(3b) Taka forma angażowania seniorów znajduje coraz większą liczbę naśladowców. Próba oddania tego złożenia przy pomocy analogicznych okazjonalizmów i dosłownych ekwiwalentów w języku polskim, takich jak akcje-seniorów (z zachowaniem oryginalnej pisowni) lub operacje seniorów jest błędna, ponieważ nie uwzględnia kontekstu wypowiedzi. Bardziej adekwatnym odpowiednikiem wyrażenia Rentner-Einsätze jest w tym kontekście konstrukcja taka forma angażowania seniorów, bazująca na znaczeniu czasownika angażować, tj. ,przyjmować do pracy, włączać kogoś w jakąś działalność, jakieś sprawy" (SJP PWN) i wyjaśniająca także znaczenie tego złożenia okazjonalnego. Tego rodzaju tłumaczenie generalizujące pozwala na równoczesne odniesienie się zarówno do działalności seniorów prowadzonej w ramach wolontariatu, jak i do działalności zarobkowej. Kreatywność językowa tłumacza przejawia się w tym przypadku w oddaniu liczby mnogiej rzeczownika Einsatz, która w polskim tekście zostaje wyrażona nietypowo - na płaszczyźnie leksykalnej przy pomocy wyrażenia taka forma i poprzez rzeczownik odczasownikowy o znaczeniu iteratywnym angażowanie, który implikuje powtarzalność czynności.

Również w przypadku innych złożeń okazjonalnych z rzeczownikiem Einsatz/Einsätze konieczny jest wybór ekwiwalentu niedosłownego uwzględniającego kontekst wypowiedzi.

(4) Bosch, Siemens oder der deutsche Ableger des Pharmakonzerns Pfizer etwa engagieren ihre eigenen Ex-Mitarbeiter für dann allerdings gutbezahlte Kurzeinsätze.

(4a) *Bosch, Siemens czy niemiecka filia koncernu farmaceutycznego Pfizer angażują swoich ekspracowników do krótkich, ale dobrze płatnych akcji/ operacji.

(4b) Bosch, Siemens czy niemiecka filia koncernu farmaceutycznego Pfizer angażują swoich byłych pracowników do krótkich, ale dobrze płatnych zleceń/zadań.

Ekwiwalenty dosłowne również w tym przypadku nie oddają właściwego znaczenia złożenia. Uszczegółowienie złożenia przez imiesłów bierny gutbezahlte Kurzeinsätze w niemieckim tekście wyjściowym wymaga również uszczegółowienia w przekładzie, dlatego bardziej trafnymi ekwiwalentami w języku polskim są w tym kontekście wyrażenia dobrze płatne zlecenia lub dobrze płatne zadania, projekty, a także krótkoterminowe umowy o pracę. Następne zadanie translatorskie polegało na przetłumaczeniu dwóch złożeń rzeczownikowych Rentner-Pools i Nachwuchsprobleme, co wymagało od tłumacza nie tylko dokładnej analizy ich części składowych, ale także uruchomienia dodatkowej wiedzy dla prawidłowego oddania ich znaczenia w języku polskim.

(5) Mit Nachwuchsproblemen haben die Rentner-Pools jedenfalls nicht zu kämpfen. Mehr als 20 Millionen Ruheständler leben schon jetzt in der Bundesrepublik. Und es werden immer mehr - auch mit staatlicher Unterstützung

(5a) *Stowarzyszenia seniorów nie muszą walczyć * z problemami młodego pokolenia. W Republice Federalnej Niemiec żyje obecnie ponad 20 milionów emerytowanych pracowników. I będzie ich jeszcze więcej - również ze_wsparciem ze strony państwa. 
(5b) *Seniorzy nie muszą konkurować *z młodą kadrą. W Republice Federalnej Niemiec jest ich już ponad 20 milionów. A dzięki wsparciu państwa będzie ich jeszcze więcej.

(5c) Pule emerytów nie muszą walczyć z brakiem pracowników. Obecnie w Niemczech jest już ponad 20 milionów seniorów, a dzięki wsparciu państwa będzie ich coraz więcej.

(5d) Koncerny zatrudniające byłych pracowników w swoich filiach nie muszą martwić się o brak pracowników. Obecnie w Niemczech jest już ponad 20 milionów seniorów, a dzięki wsparciu państwa będzie ich coraz więcej.

Złożenie rzeczownikowe Rentner-Pools wymaga od thumacza uruchomienia wiedzy z zakresu ekonomii, ponieważ jego człon główny stanowi termin ekonomiczny z języka angielskiego. Dla poprawnego tłumaczenia tego złożenia istotne jest zrozumienie, że samo oddanie terminu w języku polskim jest niewystarczające i że potrzebne jest doprecyzowanie, na czym polega tego rodzaju współpraca z seniorami. Użycie w tym kontekście rzeczownika stowarzyszenia $\mathrm{w}$ języku polskim jest błędne, ponieważ wskazuje na inny rodzaj współpracy. Termin ten profiluje głównie idee zrzeszania ludzi o wspólnych zainteresowaniach w celach niezarobkowych. Również próba thumaczenia zaproponowana w przykładzie (5c) nie jest do końca zgodna z treścią złożenia $\mathrm{w}$ tekście wyjściowym, ponieważ kładzie nacisk tylko na wierne oddanie terminu ekonomicznego i nie uwzględnia kontekstu. Wskutek tego zaproponowany ekwiwalent staje się mało czytelny dla polskiego odbiorcy. Najlepszym odpowiednikiem dla złożenia Rentner-Pools spośród analizowanych przykładów jest tłumaczenie wyjaśniające Koncerny zatrudniające byłych pracowników w swoich filiach w przykładzie (5d) aktywujące równocześnie domenę pracy zawodowej oraz domenę ekonomii.

$\mathrm{Z}$ równie ciekawym przykładem mamy do czynienia w przypadku złożenia $\mathrm{Na}$ chwuchsprobleme, które zmienia swoje znaczenie pod wpływem kontekstu, i którego przekład wymaga od tłumacza odniesienia do aktualnej sytuacji na niemieckim rynku pracy. Analiza rozwiązań translatorskich wskazuje, że główny błąd w thumaczeniu polegał w tym przypadku na zbyt dużej dosłowności i niedoprecyzowaniu relacji między członami złożenia. Błędem jest tłumaczenie tylko części składowych tego złożenia bez odniesienia się do szerszego kontekstu, tj. trudnej sytuacji na niemieckim rynku pracy. Nie chodzi w tym przypadku o problemy młodej kadry, ani o problemy związane z konkurencją między młodą a starą kadrą, jak to mogą sugerować przykłady (5a) i (5b), lecz o problemy spowodowane brakiem młodych pracowników. Mylące może się okazać również thumaczenie rzeczownika Nachwuchs jako młodej kadry, ponieważ w tym kontekście odnosi się on nie do ludzi młodych, lecz do aktywnych zawodowo seniorów. Poprawne tłumaczenie złożenia na język polski wymaga zwerbalizowania obu kwestii znaczeniowych jak w przykładach $(5 \mathrm{c})$ i (5d). Również kolejne próby thumaczenia rzeczownika Nachwuchs w dalszej części tekstu potwierdzają trudności z właściwym rozumieniem tego złożenia, prowadzą do zaburzeń spójności semantycznej w przekładzie i skłaniają do wyboru ekwiwalentu niedosłownego.

(6) In der Bonner SES-Zentrale hilft er auch bei der Senioren-Rekrutierung. Der Nachwuchs sei topfit und voller Tatendrang, erzählt Wimmerroth.

(6a) W Bonn pomaga on także przy rekrutacji emerytowanych pracowników. Młoda kadra jest w świetnej formie i ma zapał do działania, opowiada Wimmeroth. 
(6b) W Bonn, gdzie mieści się centrala SES, pomaga on także przy rekrutacji emerytowanych pracowników. Nowa kadra jest w świetnej formie i pełna zapału.

(6c) W Bonn, gdzie mieści się centrala SES, pomaga on także przy rekrutacji emerytowanych pracowników. Seniorzy są w świetnej formie i pełni zapału.

Ponowne użycie dosłownego odpowiednika młoda kadra może się więc okazać mylące, a zawarta w nim ironia trudna do uchwycenia dla polskiego odbiorcy. Rozwiązaniem w przekładzie może być np. związek wyrazowy stara nowa kadra, który łączy w sobie odniesienie zarówno do wieku, jak i do ponownego zatrudnienia lub też rezygnacja z zawartej w tekście wyjściowym ironii i wieloznaczności rzeczownika Nachwuchs na rzecz jednoznacznych ekwiwalentów, np. takich jak seniorzy, nowo zatrudnieni seniorzy, nowa kadra, nowi eksperci lub nowi rekrutanci.

Ostatnie zadanie translatorskie polegało na znalezieniu w języku polskim odpowiednika dla idiomu zum alten Eisen gehören, który w języku potocznym profiluje ,stan bycia przestarzałym i niepotrzebnym" (SI PONS), i w analizowanym tekście odnosi się do seniorów.

(7) In Suzhou gehört Weinmann dennoch zum alten Eisen.

(7a) *W Suzhou Weinmann odchodzi już jednak do lamusa.

(7b) W Suzhou Weinmann nadaje sie już na złom.

Ekwiwalent słownikowy odchodzić do lamusa przywołuje wprawdzie zamierzone w tekście wyjściowym znaczenie ,bycia starym i niepotrzebnym”, jest jednak używany w języku polskim w odniesieniu do obiektów nieożywionych, zwyczajów, a nie w odniesieniu do ludzi. Dlatego trafniejszym rozwiązaniem w tym kontekście jest wyrażenie nadawać się na złom (SI PONS) zaproponowane w punkcie (7b). Wyrażenie to nawiązuje zarówno w płaszczyźnie znaczeniowej das alte Eisen (żelazo)/złom, jak i w rejestrze stylistycznym do użytego w tekście wyjściowym idiomu i jest stosowane w języku polskim w odniesieniu i do ludzi, i do rzeczy.

\section{Implikacje dla dydaktyki przekładu}

Kognitywna teoria języka może znaleźć zastosowanie w dydaktyce przekładu, zarówno na etapie przygotowania do tłumaczenia, jak i na etapie wyboru konkretnych ekwiwalentów.

$\mathrm{Na}$ etapie przygotowania do tłumaczenia umożliwia dokładniejszą analizę semantyczną złożeń i związków frazeologicznych w tekście niż inne koncepcje badawcze, ponieważ kładzie nacisk na analizę ich znaczenia w powiązaniu z szeroko rozumianym kontekstem, a także zwraca uwagę na sposób konstruowania treści w tekście wyjściowym. Na etapie tłumaczenia pomaga w świadomym wyborze ekwiwalentów w języku docelowym. Analiza rozwiązań translatorskich wskazuje, że w przypadku złożeń transparentnych semantycznie wystarczające jest często tłumaczenie dosłowne, natomiast tłumaczenie złożeń, w których dochodzi do zmiany znaczenia jednego z członów lub złożeń okazjonalnych wymaga więcej nakładu interpretacyjnego i kreatywności ze strony tłumacza. Tłumaczenie tego rodzaju konstrukcji może na przykład wymagać od tłumacza rozszerzenia lub zawężenia konceptualizowanej sceny w przekładzie, przywołania innych komponentów wiedzy niż tekst wyjściowy lub zwerbalizowania treści, do 
których złożenie odnosi się tylko pośrednio, w celu zapewnienia zrozumienia tekstu przez odbiorcę w języku docelowym.

W przypadku tłumaczenia związków frazeologicznych, analizowanych w artykule w niewielkim stopniu, analiza kognitywna uwzględniająca sposób konstruowania treści, może pomóc rozstrzygnąć, który z proponowanych ekwiwalentów słownikowych oddaje trafniej obraz występujący w tekście wyjściowym, i tym samym będzie bardziej adekwatnym ekwiwalentem thumaczeniowym.

\section{Bibliografia}

Bär, J., Rettungsroutine. (URL http://www.duden.de). [Pobrano 27.07.2015].

DUDEN Duden Wirtschaft von A bis Z: Grundlagenwissen für Schule und Studium, Beruf und Alltag. 5. Aufl. Mannheim. (URL http://www.bhp.de). [Pobrano 27.07.2015].

Kubaszczyk, J. (2000), Kognition und Übersetzen. Über das Übersetzen von Konzepten, (w:) L. Zabrocki (red.), Glottodidactica XXVII, 77-89.

Kussmaul, P. (2007), Kreatives Übersetzen. Tübingen.

Langacker, R. (1995), Wykłady z gramatyki kognitywnej. Kazimierz nad Wisła, grudzień 1993. Lublin.

Langacker, R. (2005b), Wykłady z gramatyki kognitywnej 2. Lublin.

Langacker, R. (2009), Gramatyka kognitywna. Wprowadzenie. Kraków.

Pstyga, A. (2013), Składnia derywatów w tekście: kompozycja i dekompozycja struktur złożonych oryginału $w$ kontekście doboru odpowiedników $w$ przekładzie (na materiale rosyjskich i polskich tekstów prasowych, (w:) Slavia Meridionalis 13, 171-184. (URL https://ispan.waw.pl.pdfDOI: 10.11649/sm.2013.009). [Pobrano 22.07.2015].

Ramspeck, S. (2006), Grauer Markt, (w:): Der Spiegel 32/2006, 82-83. (URL http://www.spiegel.de/spiegel/). [Pobrano 20.07.2015].

Schwarz, M. / J. Chur (2007), Semantik. Ein Arbeitsbuch. Tübingen.

SI PONS Słownik Internetowy PONS. (URL http://pl.pons.com). [Pobrano 27.07.2015].

SJP PWN Słownik Języka Polskiego PWN. (URL http://sjp.pwn.pl/). [Pobrano 27.07.2015].

Tabakowska, E. (1995), Gramatyka i obrazowanie. Wstęp do językoznawstwa kognitywnego. Kraków.

Tabakowska, E. (2000), Przekład a językoznawstwo kognitywne, (w:) U. Dąmbska-Prokop (red.), Mała encyklopedia przekładoznawstwa. Częstochowa, 171-176.

Tabakowska, E. ([1993] 2001a), Językoznawstwo kognitywne a poetyka przekładu [Cognitive Linguistics and Poetics of Translation]. Tłum. A. Pokojska. Kraków.

Taylor, J. R. (2007), Gramatyka kognitywna. Tłum. M. Buchta, Ł. Wiraszka. Kraków. 